\title{
Marhata Sinamot at Toba Ethnic Wedding Ceremony: Antropolinguistics Study
}

\author{
Ma Samuel Rt Simanjuntak ${ }^{1}$, Flansius Tampubolon ${ }^{2}$, Jamorlan Siahaan ${ }^{3}$ \\ ${ }^{1,2,3}$ University of Sumatera, Indonesia \\ masamuelrtks@gmail.com,flansius@usu.ac.id,jamorlan@usu.ac.id
}

\begin{abstract}
The scientific title is "Marhata Sinamot at the Toba Ethnic Wedding Ceremony: Anthropology Studies". This study aims to describe the performance, indexicality and participation of Marhata Sinamot at the Toba Ethnic Wedding Ceremony. The theory used to analyze the research data is the anthropolinguistic theory proposed by Duranti. By using descriptive method. The results obtained from this study are the performance in the Marhata Sinamot traditional ceremony in the Toba Ethnic community in general, namely Marhata Sinamot. In the Toba Batak community there are signs that are used as indexicality in the Marhata Sinamot traditional ceremony, namely, (1) traditional clothes, (2) ulos. And participants in the Marhata Sinamot ceremony have Dalihan Na Tolu, namely (1) Hula-hula, (2) Bone paranak, (3) Bone parboru, (4) Boru, (5) Dongan tubu, (6) Bere paranak, (7) Bere perboru and (8) Dongan Sahuta.
\end{abstract}

Keywords

marhata sinamot; Toba ethnic; wedding

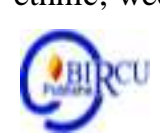

\section{Introduction}

In society, marriage is a social bond or legal agreement between individuals that forms kinship relations and is an institution in the local culture that formalizes interpersonal relationships. Marriage is the acceptance of a new status with a new set of rights and obligations or when the individual is married, the status possessed by the individual will increase, as well as the recognition of the new status by others, and the union of two or more individuals of the opposite sex, namely male and female men and women with the consent of society. That is, when a male lecturer marries, his status will increase, besides having the status of a lecturer he also has the status of a husband. The ideal marriage is carried out through various processes to achieve one household bond. One of the processes that go through in forming a family is determined by the customs that apply in each region. In general, in the process of traditional marriage ceremonies, it is known as the dowry or dowry.

Batak tribe is known as one of the largest tribes in Indonesia, as well as a tribe that adheres to its culture. In Batak kinship system, it is known as the dalihan na tolu system which functions as a rule to regulate, control and give direction to the actions of the Toba Batak people. Thus, Batak people highly uphold and preserve these cultural values because if they do not carry out the customs, they will be referred to as people who are not civilized (non-customary).

Tradition is something that is passed down from the heritage of the ancestors to the next generation in a relay descends performed by the indigenous communities that have become deeply entrenched the culture in life. (Purba, N. 2020)

Tommi Tius, (2018) in his journal The Meaning and Functions of the Tradition of Marhata Sinamot in Batak Toba Marriages said that in society, marriage is a social bond or an interpersonal legal agreement bond that forms kinship relationships and is an 
Konfrontasi Journal: Culture, Economy and Social Changes, 8 (4) December 2021, 352-363

ISSN: 1410-881X (Print), 2716-2095 (Online)

Ma Samuel Rt Simanjuntak, Flansius Tampubolon, Jamorlan Siahaan: Marhata Sinamot at Toba Ethnic Wedding Ceremony: Antropolinguistics Study

DOI: https://doi.org/10.33258/konfrontasi2.v8i4.172

http://www.konfrontasi.net/index.php/konfrontasi2

institution in the local culture that formalizes interpersonal relationships. Marriage is the acceptance of a new status with a new set of rights and obligations or when the individual is married, the status possessed by the individual will increase, as well as the recognition of the new status by others, and the union of two or more individuals of the opposite sex, namely male and female. men and women with the consent of society. That is, when a male lecturer gets married, his status will increase. besides having the status as a lecturer he also has the status as a husband. The ideal marriage is carried out through various processes to achieve one household bond. One of the processes that go through in forming a family is determined by the customs that apply in each region. In general, in the process of traditional marriage ceremonies, it is known as the dowry or dowry.

The Batak tribe is known as one of the largest tribes in Indonesia, as well as a tribe that adheres to its culture. In the Batak kinship system, it is known as the dalihan na tolu system which functions as a rule to regulate, control and give direction to the actions of the Toba Batak people. Thus, the Batak people highly uphold and preserve these cultural values because if they do not carry out the customs, they will be referred to as people who are not civilized (non-customary).

On this occasion the author talks about Marhata Sinamot at the Toba ethnic wedding ceremony. The procedure for the wedding ceremony is summarized in the culture and elements of dalihan na tolu which is a unity that cannot be separated in every traditional ceremony and is something that underlies the life of the Toba Batak ethnic community. The three elements of Dalihan Na Tolu are: (1) hula-hula, (2) Dongan tubu, and (3) boru must live in harmony, balance, and firmness, especially in every traditional ceremony. The following is an explanation of the three terms above:

1) Hula-hula role as a benefactor. The symbol of mangarsik ikan and the mangulosi symbolizes the blessings that the hula-hula gives to the boru. It was given the aim that later a child who was born into the world would become a child who is devoted to his parents and it is hoped that this child will also grow up healthy until he is an adult. For this reason, the Batak Toba people really need hula-hula as a channel of blessing.

2) Dongan Tubu as a provider of information to other Batak Toba people. Where the Batak Toba people are overseas, if they do not present their biological families in traditional ceremonies, the thing that must be done is the hula-hula to look for the closest family who are overseas whose age clearly must be older than the hula-hula in order to jointly give blessings and support the success of the traditional ceremony. .

3) Boru its role is not far from hula-hula and dongan tubu. What is slightly different is that the boru and hula-hula together prioritize the success of the traditional event. Thus the role of the boru is a series of units that cannot be separated from the hula-hula. The hula-hula is the driving force for the implementation of a Batak Toba traditional ceremony and boru is the execution in the Batak Toba traditional ceremony. (Simanjuntak: 2017).

In traditional ceremonies, there needs to be communication between the hula-hula, Dongan tubu, and also boru. From the social interactions carried out by the three parties in the Batak Toba traditional ceremony using the Batak Toba language.

Language is a construction of physical/biological reality, social reality, and symbolic reality, which together become the foundation on which ideational functions, interpersonal functions, and textual functions work. In physical/biological reality, language is used to report content or intentions as a result of observations made by speakers/writers. What is reported is whatever is in and around the speaker/writer. In social reality, language is used to perform the roles performed by speakers/writers towards listeners/readers. This role can 
be seen in the fact that language is a tool to establish and at the same time strengthen social relations. In a semiotic/symbolic reality, language expresses the content (the results of the observation) through lingual forms (text) that are in accordance with the purpose of the disclosure. In this framework, there is a relevance between the content and the form used to express it (Wiratno and Santosa: 2014).

There are several reasons for this research, namely marhata sinamot at the Toba ethnic wedding ceremony has begun to decline in the true sense, the Toba Batak people rarely use the complete tradition at wedding ceremonies and prefer the implementation of a simpler tradition because it is considered more practical. so that many elements of tradition have been omitted because the Batak Toba people do not know their meaning and use. The author is interested in studying Marhata Sinamot at the Toba ethnic wedding ceremony because there are elements of language that change, shift, increase, and decrease in the ceremony. This is due to the influence of the era of globalization and rapid technological developments that make the old values of a Batak Toba ethnic become shaky due to the entry of new values from outside. The Batak Toba people are rational thinkers and have an easy and practical life order, so that the traditional customary values of the Batak Toba people are being eroded in this day and age.

The positive impact is that the use of Indonesian words will continue to grow. The reason speaker's use these Indonesian words is because the speaker's children have been born and raised in the city so they do not understand the Batak Toba language. And if the speaker conveys his message using the Batak Toba language, the interlocutor does not understand the content of the message conveyed by the speaker. And finally the message conveyed is not realized due to miscommunication between the speaker and the interlocutor. That is the reason why speakers use Indonesian in that context.

The negative impact, namely the use of the Indonesian word, is that the Batak Toba language will be marginalized and displaced, resulting in the loss of the regional language and is also one of the reasons a regional language becomes extinct.

The shift in values is caused by the tribes who own the culture not appreciating it, as well as those caused by socio-cultural institutions or institutions that actually allow it and are less responsible, so that future generations will ignore it. In connection with the above statement, the authors are interested in conducting research on Marhata Sinamot at the Toba ethnic wedding ceremony which includes performance, indexicality, and participation that reflect Marhata Sinamot's cultural values at the Toba ethnic wedding ceremony as a philosophy of life.

In studying language, culture, and other aspects of human life, anthropolinguistics (Duranti, 1997:14) focuses on three important topics, namely performance, indexicality, and participation. Through the concept of Performance, language is understood in the process of communicative activities, actions, and performances, which require creativity. Language as a lingual element that stores cultural resources cannot be understood separately from the performances or activities of the language.

Performance is a communication event that has dimensions of a communication process that is socially, culturally, and aesthetically charged. The show has a model of action with certain signs that can be interpreted so that the act of communication can be understood. The act of communication is demonstrated, introduced to an external object, and constructed from its contextual environment. Cultural performances are performance contexts that highlight the community atmosphere, which is related to space and time.

Furthermore, this study will also examine how indexicality forms in Marhata Sinamot at the Toba ethnic wedding ceremony which explains that indexicality is one of the important symptoms in semiotics, namely a sign that replaces something, namely the 
object, not in everything, but in its reference to a bundle of ideas, which is sometimes referred to as the setting of the represent amen. In addition, this study will also examine how the form of participation in Marhata Sinamot at the Toba ethnic wedding ceremony is analyzed by Duranti's (1997) theory, namely the interaction of involvement with other people in language.

Participation (appearance) can be found in speech behavior units and also in speech activities. In addition, participation also occurs in situations that require speech (speech situations) such as eating together in the family, events that require speech (speech events) such as conversations, interviews, and dialogues with other people.

\section{Review of Literature}

\subsection{Definition of Marhata Sinamot}

Sinamot is the amount of money that has been submitted by the male family to be delivered to the female family. This amount of money is usually used by the girl's family for weddings (Sinaga, 2013: 82). The larger the sinamot received, the prouder the party receiving it will be, resulting in a shift in the meaning of sinamot in practice. Marhata sinamot, namely discussing the amount of money that will be handed over to the male family (paranak) to the female family (parboru) for the cost of the traditional ceremony. If the traditional ceremony is held at the place of the parents of the woman (parboru) where the customary term is called sold, the number of sinamot will be more than if the traditional ceremony is held at the place of the parents of the man (paranak) whose customary term is sold. At the time of marrying a daughter, sinamot ni boru is always talked about and the recipient is parboru. In the traditional tradition of ulaon parbogason nowadays, when you hear the word sinamot, it is how much money the parboru or the woman's parents will receive or a term that is often used today in modern language, dowry (sinamot ni boru). They do the calculations, buy clothes, jewelry, buy ulos, buy fish (dengke), transportation costs, especially those in the bona pasogit. All of that is said to be sinamot ni boru buying ulos, buying fish (dengke), transportation costs, especially those in bona pasogit. All of that is said to be sinamot ni boru. buying ulos, buying fish (dengke), transportation costs, especially those in bona pasogit. All of that is said to be sinamot ni boru.

In the old Batak Toba ethnic tradition, every daughter who wants to be married must be guaranteed her life in the future after becoming a "pardihuta" for her husband in front of her in-laws. The guarantee is given in the form of how much of the property of the prospective father-in-law is part of the woman to be married. This term is called manggoli, there are clear boundaries that will later become panjaean. The life guarantee that will be given to the woman is in the form of property consisting of, ruma, sopo, gold, gongs, rice fields, livestock consisting of buffalo, horses, or cows. This is called sinamot. Sinamot is property that is given by the men to the prospective son-in-law (parumaen) as a guarantee for the life of the woman after marrying their son so that the welfare of the woman's life can be guaranteed by the woman's parents (parboru). Manggoli sinamot aims so that later there will be no conflict between the descendants of the paranak. This is what the female parents (paranak) later reviewed during the tingkir tataring, when the male parents (paranak) held the pajaehon (self-reliance) event for the couple. Some of the types of property that are common in the distribution of inheritance rights. One example from both sides of the family who has complete property. 


\subsection{Anthropology Theory}

The study of language in the perspective of anthropolinguistics is associated with culture (Duranti, 1997:14). With this perspective, the study of cultural traditions that is carried out not only explores the structure of language in relation to culture, but also explores broader contexts such as situational contexts, cultural contexts, social contexts, and ideological contexts and explores contexts such as useful material and paralinguistic elements. to understand the whole tradition studied (Sibarani, 2014:20). The elements of gotong royong as a culture and aspects of mutual cooperation activities carried out by the community.

The theory used refers to the Anthropology theory by Alessandro Duranti. In the book Alessandro Duranti (1997:14) explains the interdisciplinary relationship between linguistics (linguistics) and anthropology. Duranti introduced the concept of "linguisticanthropology" which he initiated as a form of interdisciplinary area that studies "language" as a source of culture and speech as a form of cultural activity. The author of the book also points out that linguistic-anthropology also extend along with the study of ethnography which is an important element in the study of linguistics. This linguistic-anthropological study also describes the intellectual inspiration that comes from interactional relationships, based on the perspective of human activity and thought. In the book,

In studying language, culture, and other aspects of human life, the main focus of anthropolinguistics (Duranti, 1997:14) is emphasized on three important topics, namely performance, indexicality, and participation. Through the concept of performance, language is understood in the process of communicative activities, actions, and performances, which require creativity. Language as a lingual element that stores cultural resources cannot be understood separately from the performances or activities of the language.

\section{Research Method}

The research method is an attempt to collect the data needed in research (Manurung, 2010:19). In other words, the method will provide answers or instructions on the implementation of research or how this research is carried out to obtain actual data that can be proven true to the object of the problem. The author uses the ethnographic method as a research method used to examine how the process of Marhata Sinamot at the Toba ethnic wedding ceremony. The ethnographic method is one of the qualitative research methods. Ethnographic research is an activity of collecting information or data systematically about the way of life and various social activities and various cultural objects of a society. Bungin (2011: 220). The unique events and occurrences of the cultural community will attract the attention of ethnographic researchers. Where the research location used as the author is Simarmata Village, Simanindo District, Samosir Regency.

\section{Result and Discussion}

\subsection{Marhata Sinamot's Performance}

This scientific study discusses Anthropolyguistics related to three important relations that need to be considered. First, the relationship between one language and the culture concerned, which means that when we study a culture we must also learn the language and when we learn the language we must also study its culture. Performance is a person's ability in language which is shown through real abilities when speaking, listening, and writing. Understanding language as an act of communicative performance, performance has a concrete nature. (Duranti, 1997: 14-17). 
Marhata Sinamot is to talk about how many sinamot the paranak will give to parboru. This ceremony begins with the paranak coming to the parboru while bringing food to eat together. After the meal together is over, it is continued by discussing how much sinamot the paranak will give, what animals will be slaughtered, how many ulos, how many invitations and where the wedding ceremony will be held.

This performance in Marhata Sinamot is shown by a direct dialogue between paranak and parboru. For this performance itself, starting from the opening words of the parboru family such as"So in hamu raja ni amang boru nami Raja Siringoringo" and "welcome to our amang boru Raja Siringoringo" which are addressed to the paranak. Then proceed to convey each other's intentions and goals then negotiate with each other about sinamot and all the needs of the party until later finally giving sinamot to the parboru family. Direct dialogue by parboru and paranak during the course of this event will later be interspersed with umpasa and umpama according to what is being delivered.

In this performance, the language that we can hear directly at the Marhata Sinamot activity in Samosir is direct dialogue in the Toba Batak language. Not only disamosir, in every area the activity of this marhata sinamot always uses the local language of the Toba Batak community.

\subsection{Indexicality of Marhata Sinamot}

The indexicality contained in this marhata sinamot activity are: 1) Traditional Clothing, The traditional clothing of the Batak Toba tribe is woven fabric or known as ulos. Ulos is usually used like a scarf or called hande-hande. Even though in this event we use a kebaya and a suit or shirt as clothes, this ulos is still used as a complement clothing., 2) Ulos as a complement to clothing, direct ulos which has not been changed into a scarf or the like is also used as a symbol, usually this is ulos which will be given directly, not as a complement to clothing, because ulos has great meaning for tradition Batak Toba.

\subsection{Participants Marhata Sinamot}

Participants in the traditional ceremony of saur matua in the Toba Batak community. The parties involved in the traditional ceremony of saur matua in the Batak Toba community are the male party called boru and the female party called hula-hula. In the Toba Batak tradition it is often called dalihan na tolu. For the Batak Toba people, although there are different places to live, the implementation of traditional ceremonies, especially the Saur Matua ceremony, is still based on a sense of togetherness and purpose as a way of life based on the pretext of dalihan na tolu. Dalihan Na Tolu is a philosophy of life which is also referred to as the structure or unit of society in the Batak Toba society.

In the Batak Toba society, what is meant by the philosophy of dalihan na tolu is: 1) Somba Marhula-hula, 2) Manat Dongan tubu, 3) Elek Marboru. For the Batak Toba people, although there are different places to live, the implementation of traditional ceremonies, especially the Saur Matua ceremony, is still based on a sense of togetherness and purpose as a way of life based on the pretext of dalihan na tolu.

The elements in it have three forms, namely hula-hula (mother's brother), Dongan tubu (a clan/marga group), and boru (father's sister). These three elements of dalihan na tolu essentially carry their own special characteristics, namely: 


\section{1) Hula-hula}

Hula-hula is a person who is very prioritized in the implementation of the Saur Matua traditional ceremony in the Batak Toba community. Hula-hula is a family/clan that gives girls/wives. The hula-hula in the Batak Toba society must be upheld. Therefore, hula-hula is considered to have a high position in the social system of the Batak Toba people. For the Batak Toba people, the so-called hula-hula (the person's side of the wife) is a visible God. So that the blessing of the party is very influential on the life of his daughter.

The role of the hula-hula in the traditional ceremony of saur matua of the Batak Toba community is very important in the traditional party that is being held. Hula-hula occupies the most respected position in association and customs so it is ordered that all Batak Toba people must respect the hula-hula. Boru has to look at his hula-hula with respect and fear followed by disdain. Hula-hula must be maintained with great respect, this does not depend on the question of whether this boru enjoys the benefits and virtues that hula-hula emit as a magical and personal source of priority. From the explanation above, it can be concluded that the position of the hula-hula is very high for the social system of the Batak Toba people, especially in the implementation of the traditional ceremony of saur matua in the Toba Batak community.

In Natolu's pretext there are also other, more specific terms known for a Marhata Sinamot event, namely Tulang. The bones themselves are part of the hula-hula in the natolu pretext of the Batak Toba tradition. This bone is divided into two, namely the paranak, Tulang, and the Tulang parboru, each of these bones has an important role in the event of Marhata Sinamot.

\section{2) Tulang (paranak)}

At the event Marhatta Sinamotthere is something called the sijalo tintin marangkup bone, where this bone is the brother of the groom's mother. The function of the bones (paranak) itself is: to give blessings, also during this bone event usually give words of advice, also later when mangadati will convey hata sigabe-gabe and mangulosi. In the Batak Toba society, a son-in-law will be considered the daughter of the man's bones.

In some of these bone events too will give an example for example as follows:

\section{Sahat solu, sahat diparbissar ni ari Leleng ma hita mangolu, jala di iring-iring Tuhan ganup ari}

\section{3) Tulang (parboru)}

Besides Tulang (paranak)there is also a Tulang (parboru) where this is the brother of the mother of the bride. The function of this bone itself is also to give blessings and words of advice, but the difference is that this bone also gets a part of the bride's sinamot which is called upe tulang. Usually in an event Marhata Sinamot will also give an example for example as follows:

\section{Bona nipinasa, hasangkotan ni jomuran}

Tung aha pe angka na taparsinta, tontongma sai dipasu-pasu Tuhan

\section{4) Dongan tubu}

Donan Tubu (relatives of the clan) is a person who is obliged to come to the ceremony because he is a certain part that is already inherent in him. Family members who share the same clan in a patrilineal relationship (father). Dongan tubu (friends of the clan) are boys and girls whose clans do not marry each other. Every Toba must have attitudes and traits that like Dongan tubu (family relatives) wherever he is. 
The role of Dongan tubu (relatives of the clan) in the traditional ceremony of Saur Matua in the Batak Toba community is very important in the traditional ceremony held. Dongan tubu (relatives of the clan) whose role in the traditional ceremony of Saur Matua is to become a friend to carry out a traditional ceremony and become a driving force so that they must feel the same in all things. So that the event in the traditional ceremony can run well and smoothly. Fellow clans must be together and worthy of being tied up in a traditional party that is held.

The task of this dongan tubu is to support and help run the event, later this dongan tubu can also act as a parhata and will carry out negotiations with the prospective besan. In this event, Marhata Sinamot Dongan Tubu will also usually give an example or an example to reply to words of advice from hula-hula, for example as follows:

Habang pidong sibigo, paihut-ihut bulan

Saluhut akka natapangido, sai tibuma dipasahat Tuhan

\section{5) Boru}

Boru also includes being part of the traditional Saur Matua ceremony because the Boru are a group that helps many things in the Saur Matua traditional ceremony. Those belonging to boru are Hela, Hela's family (including her parents and descendants). Boru is a family member who takes a wife from a clan (another family). Boru occupies the lowest position or is said to be a servant at traditional ceremonies and in everyday life. However, even though boru functions as a servant, it does not mean that boru can be treated arbitrarily but must be taken to his heart or persuaded.

Although this boru is married to other clans, it does not break the family relationship with the clan, it increases the number of families both parties want to have offspring and lots of fortune. If the boru has many descendants, then you can find a place to complain. If the boru is a lot of fortune or wealth, the hula-hula are happy and proud because the boru likes to give to the hula. The role of the boru in the traditional ceremony of saur matua in the Toba Batak community is very important in the traditional ceremony that is being carried out. Boru as a servant at traditional ceremonies and in everyday life. However, even though boru functions as a servant, it does not mean that boru can be treated arbitrarily but must be taken to his heart or persuaded. Boru is slightly different from hela even though its position is the same as boru. Some argue that hela is more closely related to hula-hula than boru. It is true that if the daily relationship hela is closer to hula-hula than boru, but from the point of view of lineage and blood, boru is closer to hula-hula than hela.

The reason is that the day after tomorrow we can get a divorce with our boru and if we are divorced, we certainly don't mind anymore. Possibly for this reason, the Toba Batak people never call Hela by name, Hela is called by mentioning her clan. Thus, if we, as hula-hula, must be polite or careful even if the hela is below our level. This assumption in daily implementation is always maintained to avoid unwanted things. From the description above, it can be said that the traditional ceremony of Saur Matua in the Batak Toba community is carried out with good cooperation between fellow community members which is included in the pretext na tolu.

The function of this boru in marhata sinamot activities is to prepare needs or serve guests called marhobas. Boru also plays a role in cutting and providing jambar according to the direction of the parhata. This Boru also usually gives an example or example as follows:

Obut do jambulan, nidandan ni boru samara

Pasu-pasu namardongan tangiang sian hula-hula

Mambahen marsundut-sundut soada mara 


\section{6) Bere paraanak}

In tradition Marhatta sinamot The bere paranak is also usually attended by the bere paranak, where the bere paranak is the son of the father of the groom's sister. In addition, there is also a so-called ibebere which is the sister of the bere. Bere paranak is part of the boru because the bone is the hula-hula and the one who gave birth to this bere is the sister of the hula, which is called boru in Natolu's pretext.

In activities Marhata Sinamot this bere paranak will usually help in the bone event to serve the guests and also during the event it will usually give an example or example with the following example:

\section{Ampapaga dolok tu ampapaga ni humbang \\ Hita do marsogot \\ Laos hita do haduan}

\section{7) Bere parboru}

Besides bere paranak, there is also bere parboru, where the bere parboru is the daughter of the bride's father's sister. Bere parboru is also a pariban of the bride who in Toba Batak custom can actually marry each other. The bridegroom who marries this bride will be on the same level as this bere parboru. Similar to the bere paranak, the bere parboru is also part of the boru whose job is also to help serve the needs of the event.

In this event, Marhata Sinamot Bere Parboru will also usually give an example or an example with the following examples:

\section{This bona aek puli dolokni sitapongan \\ Sai tubu ma is beaten by numbers na uli Sai tamba nang pansamotan}

\section{8) Dongan sahuta}

The Marhata Sinamot event was also attended by Dongan sahuta. These Dongan sahuta are people who live in a complex or a village where the families of the bride and groom live. Usually there is no kinship with the bride and groom because it has been mixed into several different clans and families, although there are some villages where the answer is that they still have lineage ties. Usually this Dongan sahuta comes just to attend and in some areas this Dongan sahuta will later help invite other villages and other complexes and help boru in marhobas or complete party needs.

This Dongan sahuta can also usually give examples or examples in events with the following examples:

\section{Anian ma pagabe \\ Tumundalhon sitindoan \\ Arimu ma gabe molo masipaolo-oloan}

\subsection{Fungsi Dalihan Natolu}

The functions of dalihan natolu in the Batak Toba tradition are as follows:

1) A framework that includes blood relatives and marital relationship that binds a group.

2) Become a functional position provision for the Batak community Toba. So that everyone has a clear position in a custom, whether it is hula-hula, boru or dongan sauntunga.

3) Clarify that in the Batak Toba tradition everyone has the roles, duties and responsibilities of each must be carried out together without eliminating any part of the three positions of dalihan natolu in order to remain balanced and must work together. 
The following is an illustration of the seating formation when the Marhata Sinamot activity is carried out.
a. $\mathrm{T}$
: Tamu
b. $\quad \mathrm{HB}$
: Hula-hula Boru
c. HA
: Hula Hula Paranak
d. $\quad$ PB
: Parhata Boru
e. $\quad R P$
: Raja Parhata
f. PA
: Parhata Paranak

$\begin{array}{lll}\text { g. } & \text { DS } & \text { : Dekke Sitio-tio oleh Perempuan kepada laki-laki } \\ \text { h. } & \text { DT } & \text { : Dongan Tubu } \\ \text { i. } & \text { OT } & \text { : Orang tua } \\ \text { j. } & \text { OTPB } & \text { : Orang Tua Boru } \\ \text { k. } & \text { OTPA } & \text { : Orang Tua Paranak } \\ \text { l. } & \text { TS } & \text { : Tudu Tudu Sipanganon } \\ \text { m. } & \text { BS } & \text { : Bohi ni Sinamot dari laki laki ke prempuan }\end{array}$
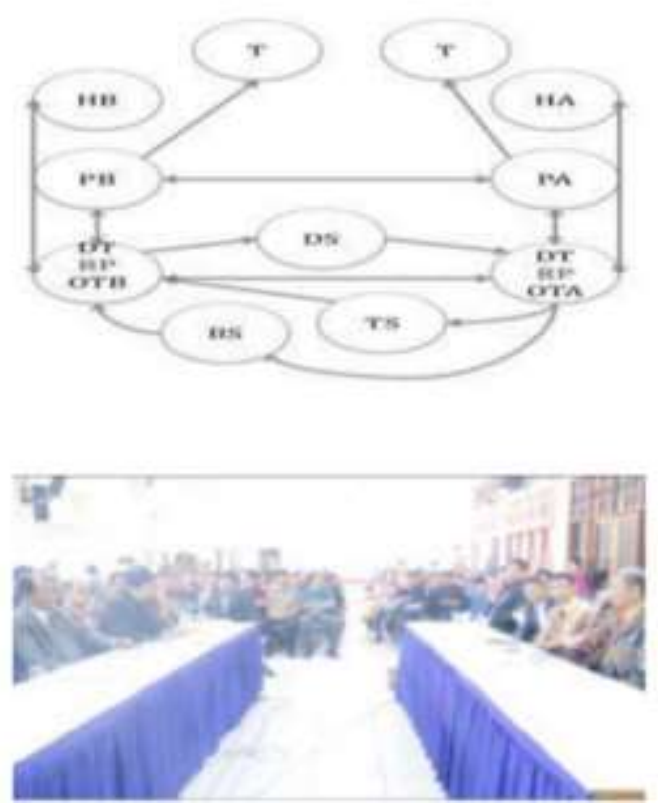

In the paranak and parboru formations, people consisting of:
1. Male parents
2. Female Parents
3. Groom
4. The Bride
5. Donan Tubu paranak/ Dongan tubu parboru
6. Bones
7. Bone parboru
8. Donan Sahuta 


\subsection{Marhata Sinamot Functions}

Marhata Sinamotis an event carried out as part of a traditional wedding ceremony for the Batak Toba community. The functions of the Marhata Sinamot activities, in the traditions of the Batak Toba people are as follows:

1. Bringing the two families of the bride and groom together legally.

2. Traditionally, it is an acknowledgment that a marriage will take place between the children of the two families, because at the time of Marhata Sinamot, there is already a traditional ceremony taking place.

3. The activity part is the most important, because sinamot which is an important part of the Batak Toba wedding customs is discussed and given half at this event, also an event to discuss all further traditional activities will be carried out.

4. It is a customary notification to Dongan Sahuta that there will be a wedding ceremony for the child of one of the residents.

\section{Conclusion}

Based on the research and description of the results of the analysis regarding the Marhata Sinamot ceremony in the Batak Toba society in terms of anthropolinguistics presented in this study, the conclusions are as follows:

1. The performance in the traditional ceremony of Marhata Sinamot in the Toba Ethnic community in general, namely, Marhata Sinamot and pointing.

2. In the Batak Toba community there is a sign that is used as a symbol indexicality in the traditional ceremony of Marhata Sinamot, namely, (1) traditional clothes, (2) ulos.

3. Participants in the Marhata Sinamot ceremony have Dalihan Na Tolu, namely (1) hulahula, (2) Dongan tubu, and (3) boru and dongan sahuta.

4. In the Marhata Sinamot activity, all the needs for the mangadati event are discussed, starting from the introduction between the two parties, the number of sinamot and other customs that must be carried out before the mangadati is carried out.

\section{References}

Alwi, Hasan, et al. (20030. Kamus Besar Bahasa Indonesia. Jakarta: Balai Pustaka.

Alwi, Hasan, et al.(2005). Kamus Besar Bahasa Indonesia. Jakarta: DepartemenPendidikan Nasional Balai Pustaka

Banjarnahor, RJ. (2019). Sinamot Dalam Perkawinan Adat Batak Toba Ditinjau Dari Hukum Adat Batak Toba. Skripsi : Universitas Sriwijaya.

Badudu, J.S and Zain. (1994). Kamus Umum Bahasa Indonesia. Yogyakarta:Pustaka Sinar Harapan.

Basaria, Ida. (2017). Bahasa dalam Ranah Budaya dan Sosial Penuturnya. Medan.USU Press.

Bungin, Burhan. (2011). Analisis Data Penelitian Kualitatif.Jakarta.Penerbit PT.Raja Grafindo.

Duranti, Alessandro (ed). (1997). Linguistic Anthropology.CambridgeUniversity Press.

Finnegan. (1992). Oral Poetry. Blomington and Indianapolis. First Midland Book Edition.

Gumperz, J.J. \& Dell Hymes (Ed.). (1972). Directions in Sosiolinguistics. New York:Rinehard \& Winston.

Haryadi, et al. (2018). ANOTASI :Undang-Undang Berdasarkan Putusan MahkamahKonstitusi Undang-Undang Republik Indonesia Nomor 1 Tahun 1974 Tentang Perkawinan. Diakses 05 Juli 2021 Di Laman 
Https://Www.Mkri.Id/Public/Content/Infoumum/Undang/Pdf/Anotasi_96_Anotasi\% 20Dody\%20UU\%201\%20Tahun\%201974\%20kawin.Pdf

Hasugian, Relly Monika. (2017). Upacara Merbayo Etnik Pakpak : AnalisisAntropolinguistik. . (Tesis).Medan : PascaSarjana USU.

Hasugian, Relly Monika.(2017). Upacara Kematian Saur Matua BatakToba : Analisis Tradisi Lisan. LINGUA, Vol. 14, No. 2,September 2017.

Pardosi, J. "Makna Simbolik, Umpasa, Sinamot, dan Ulos pada Adat Perkawinan Batak Toba". Jurnal Ilmiah dan Sastra. Vol. 4. No. 2. Tahun 2008, hlm. 106.

Kridalaksana, Harimurti. 2008. Kamus Linguistik.Jakarta: PT. Gramedia PustakaUtama.

Situmorang, L,T. (2017). Makna Pemberian Sinamot Pada Perkawinan Batak Toba Dalam Kajian Etika Deontologi. Immanuel Kant. Skripsi. UGM

Mahsun.(2005).Metode Penelitian Bahasa: Tahapan Startegi,Metode,danTekniknya (Edisi Revisi).Jakarta: Raja Grafindo Persada.

Manik, Helga Septiani. (2012). Makna dan Fungsi Tradisi Sinamot dalam Adat PerkawinanSukubangsa Batak Toba di Perantauan Surabaya. Jurnal : BioKultur, Vol.I/No.1/Januari-Juni 2112, hal. 1a9.

Moleong, Lexy J. (2017). Metodologi Penelitian Kualitatif (Edisi Revisi).Bandung: Rosdakarya.

Purba, N. (2020). The Use of Simalungun Language by Anak Boru Sanina in the Simalungun Wedding Ceremony (Sociolinguistic Studies). Lakhomi Journal: Scientific Journal of Culture. 1-7

Simalango R. Fungsi Uang Jujur (Sinamot) Pada Perkawinan Menurut Adat Masyarakat Batak Toba. JUPIIS, Vol. 3. No. 11. Tahun 2011, hlm 30

Sibarani, Robert. (2004). Antropolinguistik: Antropologi Linguistik danLinguistik Antropologi. Medan: Penerbit Poda.

Sibarani, Robert. (2012). Kearifan Lokal Hakikat, Peran dan Metode Tradisi Lisan.Medan.

Sibarani, Robert. (2015). Pendekatan Antropolinguistik Terhadap Kajian Tradisi Lisan. Jurnal : RETORIKA, Volume 1, Nomor 1, April 2015

Simatupang, RM. (2016). Adat Budaya Batak dan Biografi. Tangerang:Bornrich Publishing.

Sinaga, Richard. (2013). Perkawinan Adat Dalihan Natolu. Jakarta : Dian Utama.

Sugiyono. (2013).Metodelogi Penelitian Kuantitatif, Kualitatif dan R\&D.Bandung: ALFABETA.

Silalahi, Ulber. (2006). Metode Penelitian Sosial. Bandung: UniversitasParahyanganPress.

Sudaryanto. (1993). Metode dan Aneka Teknik Analisis Bahasa.Yogyakarta: DutaWacana University Press.

Sudaryanto. (2015). Metode dan Teknik Analisis Bahasa. Yogyakarta:SanataDharma University Press.

Tampubolon, Flansius. (2010). Umpasa Masyarakat Batak Toa Dalam Rapat Adat : Suatu Kajian Pragmatik (Tesis). Medan : Pascsarjana USU.

Wiratno dan Santosa. (2013). Bahasa, Fungsi Bahasa, dan Konteks Sosial. BING4214/MODUL 